\title{
Front Matter: Volume 7672
}

, "Front Matter: Volume 7672," Proc. SPIE 7672, Polarization: Measurement, Analysis, and Remote Sensing IX, 767201 (8 May 2010); doi:

$10.1117 / 12.867423$

SPIE Event: SPIE Defense, Security, and Sensing, 2010, Orlando, Florida, United SPIE. States 


\section{PROCEEDINGS OF SPIE}

\section{Polarization: Measurement, Analysis, and Remote Sensing IX}

David B. Chenault

Dennis H. Goldstein

Editors

7-8 April 2010

Orlando, Florida, United States

Sponsored and Published by

SPIE

Volume 7672

Proceedings of SPIE, 0277-786X, v. 7672 
The papers included in this volume were part of the technical conference cited on the cover and title page. Papers were selected and subject to review by the editors and conference program committee. Some conference presentations may not be available for publication. The papers published in these proceedings reflect the work and thoughts of the authors and are published herein as submitted. The publisher is not responsible for the validity of the information or for any outcomes resulting from reliance thereon.

Please use the following format to cite material from this book:

Author(s), "Title of Paper," in Polarization: Measurement, Analysis, and Remote Sensing IX, edited by David B. Chenault, Dennis H. Goldstein, Proceedings of SPIE Vol. 7672 (SPIE, Bellingham, WA, 2010) Article CID Number.

ISSN 0277-786X

ISBN 9780819481368

Published by

SPIE

P.O. Box 10, Bellingham, Washington 98227-0010 USA

Telephone +1 3606763290 (Pacific Time) · Fax +1 3606471445

SPIE.org

Copyright (c) 2010, Society of Photo-Optical Instrumentation Engineers

Copying of material in this book for internal or personal use, or for the internal or personal use of specific clients, beyond the fair use provisions granted by the U.S. Copyright Law is authorized by SPIE subject to payment of copying fees. The Transactional Reporting Service base fee for this volume is $\$ 18.00$ per article (or portion thereof), which should be paid directly to the Copyright Clearance Center (CCC), 222 Rosewood Drive, Danvers, MA 01923. Payment may also be made electronically through CCC Online at copyright.com. Other copying for republication, resale, advertising or promotion, or any form of systematic or multiple reproduction of any material in this book is prohibited except with permission in writing from the publisher. The CCC fee code is 0277-786X/10/\$18.00.

Printed in the United States of America.

Publication of record for individual papers is online in the SPIE Digital Library.

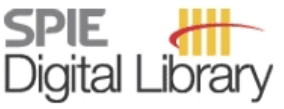

SPIEDigitalLibrary.org

Paper Numbering: Proceedings of SPIE follow an e-First publication model, with papers published first online and then in print and on CD-ROM. Papers are published as they are submitted and meet publication criteria. A unique, consistent, permanent citation identifier (CID) number is assigned to each article at the time of the first publication. Utilization of CIDs allows articles to be fully citable as soon they are published online, and connects the same identifier to all online, print, and electronic versions of the publication. SPIE uses a six-digit CID article numbering system in which:

- The first four digits correspond to the SPIE volume number.

- The last two digits indicate publication order within the volume using a Base 36 numbering system employing both numerals and letters. These two-number sets start with 00, 01, 02, 03, 04 , 05, 06, 07, 08, 09, OA, OB ... 0Z, followed by 10-1Z, 20-2Z, etc.

The CID number appears on each page of the manuscript. The complete citation is used on the first page, and an abbreviated version on subsequent pages. Numbers in the index correspond to the last two digits of the six-digit CID number. 


\section{Contents}

vii Conference Committee
ix Introduction

\section{SESSION 1 ALGORITHMS}

767202 Linear high-boost fusion of Stokes vector imagery for effective discrimination and recognition of real targets in the presence of multiple identical decoys [7672-01]

A. El-Saba, Univ. of South Alabama (United States); W. A. Sakla, Texas A\&M Univ. (United States)

767203 3D shape reconstruction of optical element using polarization [7672-02]

M. Vedel, N. Lechocinski, S. Breugnot, Bossa Nova Technologies (United States)

767204 Pose estimation of unresolved targets using polarimetric imaging [7672-03]

M. Gartley, Rochester Institute of Technology (United States); P. Erbach, L. Pezzaniti, Polaris Sensor Technologies, Inc. (United States)

767205 MidIR and LWIR polarimetric sensor comparison study [7672-04]

K. Gurton, M. Felton, U.S. Army Research Lab. (United States); R. Mack, D. LeMaster, Air Force Research Lab. (United States); C. Farlow, Digital Fusion Inc. (United States); M. Kudenov, College of Optical Sciences, The Univ. of Arizona (United States); L. Pezzaniti, Polaris Sensor Technologies, Inc. (United States)

\section{SESSION 2 INSTRUMENTS}

767206 Synthetic Aperture Imaging Polarimeter [7672-33]

M. E. Roche, D. B. Chenault, J. P. Vaden, A. Lompado, Polaris Sensor Technologies, Inc. (United States); D. Voelz, New Mexico State Univ. (United States); T. J. Schulz, Michigan Technological Univ. (United States); R. N. Givens, V. L. Gamiz, Air Force Research Lab. (United States)

767207 SPITFIRE multi-band short-wave and mid-wave polarimetric camera [7672-06]

H. J. Patel, R. T. Mack, D. A. LeMaster, J. S. Harris, Air Force Research Lab. (United States);

D. Forrai, L-3 Communications Cincinnati Electronics (United States); J. M. Servaites, Air Force Research Lab. (United States)

767208 Demonstration of a polarization grating imaging spectropolarimeter (PGIS) [7672-07] J. Kim, M. J. Escuti, North Carolina State Univ. (United States)

767209 White-light Sagnac interferometer for snapshot polarimetric and multispectral imaging [7672-08]

M. W. Kudenov, M. E. L. Jungwirth, E. L. Dereniak, College of Optical Sciences, The Univ. of Arizona (United States); G. R. Gerhart, U.S. Army TARDEC/RDECOM (United States) 
7672 OA Continuous outdoor operation of an all-sky polarization imager [7672-09]

J. A. Shaw, N. J. Pust, B. Staal, J. Johnson, A. R. Dahlberg, Montana State Univ. (United States)

$7672 \mathrm{OB}$ Stokes imaging polarimetry using a single ferroelectric liquid crystal modulator [7672-10]

L. Gendre, A. Foulonneau, L. Bigué, Univ. de Haute Alsace (France)

\section{SESSION 3 DEVICES AND COMPONENTS}

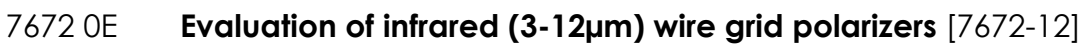

D. H. Goldstein, P. Erbach, Polaris Sensor Technologies, Inc. (United States)

7672 OF Tunable liquid crystal filters including variable FWHM control [7672-13]

P. A. Searcy, P. Wagner, R. A. Ramsey, J. Powell, T. G. Baur, Meadowlark Optics, Inc. (United States)

$76720 \mathrm{G}$ Integrated high resolution division of focal plane image sensor with aluminum nanowire polarization filters [7672-14]

V. Gruev, R. Perkins, T. York, Washington Univ. in St. Louis (United States)

\section{SESSION 4 CALIBRATION AND ANALYSIS}

$7672 \mathrm{OH} \quad$ Parallelization of polarization state generation and detection for fast Mueller matrix polarimetry [7672-18]

S. Tripathi, K. C. Toussaint, Jr., Univ. of Illinois at Urbana-Champaign (United States)

SESSION 5 SPECIAL TOPIC: MEASURING POLARIZATION SENSING IN INVERTEBRATES

$7672 \mathrm{OL}$ Methods in arthropod retinography for evaluation of spectral polarization sensitivity [7672-20]

M. F. Wehling, D. H. Goldstein, Air Force Research Lab. (United States)

\section{SESSION 6 REMOTE SENSING}

7672 OM Correlation of environmental data measurements with polarimetric LWIR sensor measurements of manmade objects in natural clutter [7672-21]

J. McCarthy, Defence Science and Technology Organisation (Australia) and U.S. Army Armament Research, Development and Engineering Ctr. (United States); M. Woolley,

L. Roth, U.S. Army Armament Research, Development and Engineering Ctr. (United States)

$76720 \mathrm{~N} \quad$ Polarimetric effects in nonpolarimetric imaging [7672-22]

R. P. Kauffman, Lockheed Martin Information Systems and Global Services (United States);

M. Gartley, Rochester Institute of Technology (United States)

7672 OP Lidar polarization discrimination of bioaerosols [7672-24]

X. Cao, Royal Military College of Canada (Canada); G. Roy, Defence Research and Development Canada (Canada); R. Bernier, Les Instruments Optiques du St-Laurent Inc. (Canada) 
$76720 Q$ Contrast evaluation of the polarimetric images of different targets in turbid medium: possible sources of systematic errors [7672-25]

T. Novikova, Ecole Polytechnique (France); A. Bénière, F. Goudail, Institut d'Optique Graduate School (France); A. De Martino, Ecole Polytechnique (France)

\section{SESSION 7 SIGNATURES}

7672 OR Comparison of the inversion periods for MidIR and LWIR polarimetric and conventional thermal imagery [7672-27]

M. Felton, K. P. Gurton, U.S. Army Research Lab. (United States); J. L. Pezzaniti, D. B. Chenault, Polaris Sensor Technologies, Inc. (United States); L. E. Roth, U.S. Army Armament Research, Development and Engineering Ctr. (United States)

7672 OS Improved subsurface land mine recognition using high-boost fusion between passive Stokes vector imagery [7672-28]

A. El-Saba, Univ. of South Alabama (United States)

7672 OT Dynamic scene generation, multimodal sensor design, and target tracking demonstration for hyperspectral/polarimetric performance-driven sensing [7672-26]

M. D. Presnar, Rochester Institute of Technology (United States) and Air Force Institute of Technology (United States); A. D. Raisanen, D. R. Pogorzala, J. P. Kerekes, Rochester Institute of Technology (United States); A. C. Rice, Numerica Corp. (United States)

Author Index 
Downloaded From: https://www.spiedigitallibrary.org/conference-proceedings-of-spie on 26 Apr 2023

Terms of Use: https://www.spiedigitallibrary.org/terms-of-use 


\title{
Conference Committee
}

\author{
Symposium Chair
}

Michael T. Eismann, Air Force Research Laboratory (United States)

Symposium Cochair

William Jeffrey, HRL Laboratory, LLC (United States)

Conference Chairs

David B. Chenault, Polaris Sensor Technologies, Inc. (United States)

Dennis H. Goldstein, Polaris Sensor Technologies, Inc. (United States)

Program Committee

Eustace L. Dereniak, College of Optical Sciences, The University of Arizona (United States)

Aed M. El-Saba, University of South Alabama (United States)

Michael G. Gartley, Rochester Institute of Technology (United States)

Kristan P. Gurton, Army Research Laboratory (United States)

Joseph A. Shaw, Montana State University (United States)

J. Scott Tyo, College of Optical Sciences, The University of Arizona (United States)

Kyle J. Zeringue, Photon Research Associates, Inc. (United States)

\section{Session Chairs}

1 Algorithms

David B. Chenault, Polaris Sensor Technologies, Inc. (United States)

2 Instruments

Joseph A. Shaw, Montana State University (United States)

3 Devices and Components

Eustace L. Dereniak, College of Optical Sciences, The University of Arizona (United States)

$4 \quad$ Calibration and Analysis

Aed M. El-Saba, University of South Alabama (United States)

5 Special Topic: Measuring Polarization Sensing in Invertebrates

David B. Chenault, Polaris Sensor Technologies, Inc. (United States) 
6 Remote Sensing

Joseph A. Shaw, Montana State University (United States)

$7 \quad$ Signatures

Michael G. Gartley, Rochester Institute of Technology (United States) 


\section{Introduction}

The latest work in polarization research is contained within this volume, with an emphasis on remote sensing for defense and security applications. There were more talks than ever that described results of measurements taken with mature, well calibrated sensors. Several talks discussed new and refined polarization devices with better performance and improved size and angle response. The one biological polarization talk generated a great deal of interest and produced a number of questions for the speaker. The conclusion that an attendee to the conference would come to is that the field continues to mature through advances in instrumentation, modeling, and processing.

These proceedings are made up of 22 papers from six conference sessions. The first session consisted of three papers on algorithms followed by a session on instruments. The second day started with a session on devices and components. A special topic session on measuring polarization sensing in invertebrates presented the only biological polarization paper. This was followed by a session on remote sensing and a session on signatures. All of the papers in the last two sessions primarily described measurements with less emphasis on the instruments themselves, highlighting that polarization sensing is becoming more routine and that applications are becoming more numerous.

This conference marks the 12th year in a row that a polarization conference has been held due in part to the high interest in the technology, the maturity of the sensors, and the corresponding ability to collect, analyze, and exploit high quality data. Over the last six years, the polarization conferences have alternated from the SPIE Annual Meeting in odd years to the SPIE Defense + Security symposium in even years. The 11 prior conferences of 2009, 2008, 2007, 2006, 2005, 2004, 2003, 2002, 2001, 2000, and 1999 are documented in Proceedings of SPIE Vol. 7461, 6972, 6682, 6240, 5888, 5432, 5158, 4819, 4481, 4133, and 3754, respectively. Previous conferences in this series include Polarization: Measurement, Analysis, and Remote Sensing held in San Diego in 1997 (Proceedings of SPIE Vol. 3121) and Polarization and Remote Sensing held in San Diego in 1992 (Proceedings of SPIE Vol. 1747). Conferences on polarization, without the specific emphasis and inclusion of the remote sensing application and entitled Polarization Analysis and Measurement I and II (Proceedings of SPIE Vols. 1746 and 2265), were held in San Diego in 1992 and 1994. Earlier conferences include Polarimetry: Radar, Infrared, Visible, Ultraviolet, and X-Ray (Proceedings of SPIE Vol. 1317, 1990), and Polarization Considerations in Optical Systems I and II (Proceedings of SPIE Vol. 891 in 1988 and Vol. 1166 in 1989). 
Our appreciation is given to our program committee members and session chairs for their efforts in making this conference a success, and to the contributing authors for the high quality of the papers in this volume.

David B. Chenault Dennis H. Goldstein 